\title{
Divorce Reform and the Image of the Child
}

\section{CHRISTINE PIPER*}

\section{INTRODUCTION}

In recent years marriage and divorce have again become the focus of a debate which has attracted and digested in varying degrees the contributions of academics, practitioners, politicians, religious leaders and the popular press. It has resulted in a series of official documents from the Inter-departmental Committee's Report on Conciliation in 1983 through the Law Commission Working Papers to the White Paper on Divorce Reform ${ }^{1}$ and, now, Parts I and II of the Family Law Bill 1995. It has been argued that the proposed legislation does not pay sufficient attention to the interests of children. James and Lyon note that "although there are now in excess of 160,000 children under the age of 16 each year who experience the divorce of their parents, the White Paper contains in total little more than two pages referring to the needs of children in divorce", supporting their contention that there is an "almost complete absence of discussion concerning children" in the White Paper. ${ }^{2}$

However, the scattered passages which make up those two pages and the similar references in the preceding Consultation Paper, ${ }^{3}$ can be interpreted quite differently if quantity is not the yardstick for importance. Instead I will argue that the child of divorcing parents is given

\footnotetext{
* Centre for the Study of Law, the Child and the Family, Law Department, Brunel University, Uxbridge, UB8 3PH.

I wish to thank my MA class on the Children as Victims and Offenders module and my colleagues Alison Diduck, Felicity Kaganas and Michael King for their helpful comments on an earlier version of this article which was presented as a paper, 'The Child as Victim of Divorce' at the conference on Government Policies and their Effects on Children held at the University of Central Lancashire in conjunction with the Social Policy Association, 6 September 1995. I am also grateful to the anonymous referees of this article for their suggestions.
}

a high profile in these documents and that the particular image of the child - the conceptualisation or "mental representation of something not present to the senses" ${ }^{4}$ - which is 
drawn on and reconstituted in these documents is crucial to the development both of government policy in relation to the family and of the operation of family law.

The following assertions are to be found in the Foreword to the Consultation Paper:

... Almost inevitably the breakdown of a marriage is hard for one or both of the parties and especially for the children. I believe that a good divorce law ... should seek to eliminate unnecessary distress for the parties and particularly for their children in those cases where a marriage has broken down irretrievably. ...

It is clear that, when a marriage breaks down and there are children of the marriage, they are very vulnerable to consequent damage. [my italics] ${ }^{5}$

This is echoed in Chapter 5 of the White Paper which begins, "Separation and divorce constitute a painful process for all the family members concerned but particularly for the children". ${ }^{6}$ Prominence is also given to children in the discussion in the White Paper of seven "Criticisms of Current Divorce Law". These include three points which, together, convey the idea that the decision to divorce is not currently sufficiently 'thought through' or child-centred: "The system does nothing to save saveable marriages" ${ }^{7}$ because it allows divorce "after a period of just a few months [the parents] having had few chances to stop and consider whether this is the best outcome for them and their children",' "Divorce can be obtained without proper consideration of the consequences and implications", ${ }^{9}$ and "The system makes things worse for the children". ${ }^{10}$

These basic assumptions that the current divorce process is `bad' for children and that the breakup of their parents' marriage can itself be a cause of harm to children are, it is true, not discussed in any depth, the White Paper referring directly to only one recent piece of research ${ }^{11}$ that "has confirmed that marital conflict is harmful to children". ${ }^{12}$ However, references to these assumptions are effectively placed. For example, the Government's objectives, summarised in paragraph 3.5, are five-fold with the first two relating to marriage saving and possibly also the third, "to ensure that the parties understand the practical consequences of divorce ${ }^{13}$ before taking any irreversible decision", in that para. 4.33 makes the point that couples who have thought through the consequences may "find some way of re-negotiating their relationship so that they and their children can have a future together". Such objectives should be read alongside the fact 
that the preceding Consultation Paper ${ }^{14}$ had repeated the assertion of the Law Commission Report The Ground for Divorce that "The children would usually prefer their parents to stay together" ${ }^{15}$ However, "where divorce is unavoidable" the objectives of the proposals are: "... to minimise the bitterness and hostility between the parties and to reduce the trauma for the children; and to keep to the minimum the cost to the parties and the taxpayer". ${ }^{16}$ It is later made clear that there is a relationship between the two parts of this fourth objective:

... it is conflict between the parents which has been linked to greater social and behavioural problems among children rather than the separation and divorce itself. A reduction in bitterness and hostility was seen by consultees as a central objective in reducing the harm that might be done to children of the marriage. ${ }^{17}$

A divorce process based on a requirement to reflect rather than recriminate will help to reduce conflict and encourage cooperation, which will in turn minimise the distress caused to children. ${ }^{18}$

Conflict is harmful to children and the Government is of the view that the reduction of conflict should be high on the list of objectives for a good divorce process. ${ }^{19}$

Therefore, the aim of conflict reduction is justified because of the damage to children ${ }^{20}$ and the greater use of mediation is justified because it will reduce conflict.

Consultees considered that, in general, the advantages of mediation outweighed its disadvantages. Advantages included the reduction of conflict between the couple leading to a reduction in trauma for the children. ${ }^{21}$

The Government agrees that bitterness and hostility are reduced through the mediation process and couples are helped to manage conflict to the benefit of their children and themselves. $^{22}$

Mediation is also encouraged because it teaches parental communication and because it promotes parental responsibility ${ }^{23}$ - both deemed to further the child's welfare. The focus on the reduction of hostility for the benefit of the child also supports the proposal for a "first port of call" which is essentially an information giving session:

The Government is of the view that couples need a better understanding ... of the effects of divorce on children before their marriage is dissolved. ... As discussed earlier, reduction and management of conflict is essential if the effects of divorce on children are to be minimised. It is equally important, however, for parents to be informed about their 
continuing parental responsibility, what this means, and how to deal with children who are suffering distress as a result of the breakdown in their parents' marriage. ${ }^{24}$

It is, therefore, possible to argue that a quite specific understanding of the child's nature and needs is conveyed. This representation of the child as a vulnerable person who does not want her parents to divorce, who is damaged by both the process of divorce and its consequences and who is powerless to affect the divorce process dominates both the Consultation Paper and the White Paper and provides justification for the key proposals in these documents and resulting proposals for legislation. In effect, the debate surrounding divorce reform has led to the emergence of a 'popular' and powerful image of the child as 'the victim' of divorce, that is, as a passive participant in the divorce process and one needing protection from the consequences of divorce. ${ }^{25}$

\section{THE CHILD AS VICTIM}

This image of the child as a victim, to be protected without qualification by the legal system and other institutions regulated by law because he or she holds no responsibility for a damaging situation, is not novel. In medieval and early modern England such protection had been confined largely to those minors who owned property and who were perceived as the victims of rapacious guardians. Whilst, therefore, the court "historically regarded itself as the protector of the minor against the manipulation of adults", ${ }^{26}$ for propertyless children, the majority, the "long tradition of the court's right to protect children against adult exploitation" ${ }^{27}$ required the creation of offences and the imposition of duties by legislation, notably the Tudor Poor Laws, nineteenth century factory and mines regulations and, since the Prevention of Cruelty to and Protection of Children Act 1889, the labelling of cruelty to children as a specific criminal act. In the context of legislation over the last 150 years, therefore, the child has been perceived and 'processed' principally as a victim, to whom attributions of culpability and responsibility are not possible, when the child is a victim of assault and abuse and, specifically, a victim of parental failure and cruelty or a victim of ill treatment by an employer. ${ }^{28}$ Within legal communications, therefore, the 
concept of the child as a victim to be protected operates as a particular `semantic artifact', ${ }^{29}$ one of several "constructs ... produced by the legal discourse itself" ${ }^{\prime 30}$ which avoid the need to deal with all the complexities and contradictions which are inherent in a 'real' child and which 'fit' into law's own procedures and functions. ${ }^{31}$

Yet this analysis is misleading if it suggests an unproblematic link between the existence of offences or duties which carry the potential to construct a child as victim and the availability of powerful images of children as victim in, say, a political discourse. For example, despite the growth of victimology ${ }^{32}$ and the developing policy emphasis on victims of crime,

[T] here is very little mention of children as victims of crime. The victimization of children is seen solely in terms of child abuse, physical and sexual. ... The term 'child abuse is used to describe acts which may fail to be recorded as crime, and such cases may be diverted out of the criminal justice process into civil protection proceedings. As a result, interest and concern about child victimization has developed largely outside a criminological framework .... .

Therefore, whilst adults are generally accorded the status of victim when disadvantaged by the criminal action of another, the 'victim of crime' status is awarded more restrictively to children. So often what happens to children is not labelled in such a way that a criminal offence is denoted - evident, for example, in the references to 'abuse' rather than 'assault', regardless of whether criminal or civil proceedings are contemplated. The current image of the child as victim of crime may be modified by attention, for example, to bullying in schools ${ }^{34}$ and to secondary victimisation in relation to domestic violence, ${ }^{35}$ but it is still a relatively narrow construction. ${ }^{36}$ In addition, those offences committed against children which are processed as crimes may be dealt with in ways which accord less importance to them because the impact of crime is assessed in relation to adult criteria. So, for example, Morgan and Zedner discuss bicycle theft which does not usually lead to a high level of police response because of the relatively low level of monetary value involved and yet, for a child, may mean the theft of their most valuable possession, possibly having been `earned' and having facilitated independence. 
There are two obvious reasons why this has happened: a focus on the `welfare of the child', with social work 'control' of child abuse, and the lack of any "political impetus" for recognition of the needs of child victims more generally. ${ }^{37}$ The resulting "tendency to marginalise children as victims of crime" ${ }^{138}$ has practical implications: children are denied the benefits of recognition as victims of acts that, if committed against adults, would be labelled as criminal. Denunciation of the offender does not occur or is not public (for example where abuse leads to care not criminal proceedings) and there are no 'victim support' services. This marginalisation of children as victims of crime has also contributed to the development of a popular image of the child who, inter alia, offends, which is almost exclusively an image of the child `as offender'. As a result there is no prevalent image of the child as perpetrator and victim of crime despite research which shows that the categories of children who offend and children who are victims of crime "are not mutually exclusive but are often products of each other". ${ }^{39}$ For example, "being an offender puts individuals in situations which ensure that they are more likely to be victims of crime than the rest of the population". ${ }^{40}$

\section{VICTIMS OF PARENTAL HOSTILITY}

The development of a powerful image of the child `as victim' in relation to divorce reform is, therefore, of greater significance because in only a limited range of circumstances and situations has there been a relevant consensus that a child should be protected through state policy and action, notwithstanding conflicting adult interests. In addition, comparatively rarely is public policy based on the image of the child as victim. The current intense debate in the UK on educational policy, for example, is conducted almost entirely around concepts of parental rights and societal needs (for a flexible workforce or 'disciplined' youth). Yet in relation to divorce, whilst the Consultation and White Papers reveal a political consensus on the nature and universality of the harm, it is far from clear there is societal consensus that divorce is a social problem or that it is a problem for the reasons constituted in the political documents. The 
assumptions which underlie the government's proposals draw on a different consensus - one which has emerged in the last two decades among child welfare professionals through their acceptance of the likelihood that the child, during and after parental separation, is psychologically harmed by inter-parental hostility and lack of contact with one of her parents the latter harm being assumed to follow the former.

Research and professional experience in the social and 'psy' sciences suggests a complex picture of family life after parental separation. In 'The Rights and Wrongs of Children'(1983) ${ }^{41}$ Freeman's chapter, entitled 'Children as Victims of the Divorce Process', was, amongst other things, a consciousness-raising exercise in relation to the needs and welfare of children whose parents separate. He referred to what was then recent research by Wallerstein and Kelly, stating that "Divorce causes trauma" and "the children of divorce ... are amongst the most vulnerable members of society" ${ }^{\prime 2}$ but it was a wide-ranging and detailed review which drew on a range of images of the child in relation to divorce rather than the one image evident in recent policy documents.

What is interesting is that a particular professional consensus is now endorsed and communicated so enthusiastically and unequivocally in policy documents and judicial comment. It was the much more general concern of the Royal Commission on Marriage and Divorce, reporting in 1956, about the effects on children of the disruption of family life and a lack of confidence that parents could safely be left to make arrangements when emotionally affected by their divorce ${ }^{43}$ that led to the requirement that the court should oversee arrangements for all children of divorcing parents (now section 41 of the Matrimonial Causes Act 1973). The Robinson Report in the early 1980s also noted in broad terms: "It is accepted on all sides that the consequences of marriage breakdown and divorce are at best unpleasant for the spouses and the children and at worst productive of serious and prolonged anguish and of injury to children". ${ }^{44}$ The more recent Consultation Paper in its Foreword was more specific, "Such damage [to 
children of the marriage] is particularly likely where the marriage has ended in bitterness and where the children do not have a continuing reasonable relationship thereafter with both parents". ${ }^{45}$ The White Paper makes the point even clearer:

it is conflict between the parents which has been linked to greater social and behavioral problems among children ... A reduction in bitterness and hostility was seen by consultees as a central objective in reducing the harm that might be done to children of the marriage. ${ }^{46}$

The influence of an increasingly narrow version of that perceived professional consensus is also evident in the rhetorical question of Judge Pearce, made in relation to the Children Act 1989: "The prime objective is, and always has been, the best interest of the child. The rest follows on because what could be better for the child than to have parents and other carers sharing parental responsibility and ordering their family affairs by agreement?". ${ }^{47}$ This image of the child as the victim of parents in conflict is, therefore, not confined to the divorce reform documents - it has also underpinned recent legislation, notably the Children Act 1989. As Roche argues, "Part of the agenda behind the Act was ... the idea of children as 'victims' of their parents' divorce". ${ }^{48}$ "Increasingly children were seen as the innocent victims of adult-relationship breakdown" ${ }^{49}$ and law's role was to be that of "lowering the stakes" in the parental battles, again to reduce interparental conflict. To achieve that the Act created a new legal concept of parental responsibility, ${ }^{50}$ giving a power to all married parents which is inalienable except via adoption proceedings and which has been 'marketed' as facilitating the reduction of parental hostility and the encouragement of cooperative parenting. ${ }^{51}$

The idea of the child as victim of parental conflict is also evident in judicial comments in relation to custody (residence) and access (contact) cases over the last two decades ${ }^{52}$ and, arguably, more so since the implementation of the Children Act $1989 .{ }^{53}$ Even though legislation has given parents the right to ask the court to order contact (when the care-giving parent is either denying any contact or contact in the form requested), courts have maintained a legal fiction - that contact is the right of the child - which feeds into the representation of the child as a victim if not in 
contact with both parents. ${ }^{54}$

Access should be regarded as a basic right of the child ... no court should deprive a child of access unless it was wholly satisfied that it was in the interests of that child that access should cease. $^{55}$

The starting point, always, is that every child has a right to be brought up in the knowledge of his non-custodial parent. That is a right which the courts are determined to preserve ... Their right to have their welfare served by re-establishing contact with their father at the earliest possible moment requires that the fullest attention should now be given [to that], with the best possible legal and medical help available ... . ${ }^{56}$

What has occurred is that the relatively narrow popular and legal images of the child as victim have been reconstructed, but not to embrace victimisation by any adult or child committing against her any crime, including those offences relating to children and adults alike. Rather, it has been extended to include victimisation from another form of parental 'abuse'. To the 'popular' image of the child as victim of physical or sexual abuse has been added the child as victim of inter-parental hostility and of emotional abuse. So powerful is this recent conceptualisation of the child as victim of parental separation and conflict that, as Jones and Parkinson have noted in relation to the child's contact with the `absent' parent, "there has been in the past a discernible reluctance of courts in England, Australia and elsewhere, to deny access entirely" even when the parent-child relationship had involved sexual abuse - that other great danger in available images of child victims. ${ }^{57}$

\section{MAKING PARENTS RESPONSIBLE}

Policy documents have conveyed the message that the existence of the potential danger of conflict induced trauma is proven by a large amount of recent research which suggests that divorce may produce children who are more likely to be unhappy, to underachieve and to become criminals than peers whose parents stay together or who live cooperatively after divorce. ${ }^{58}$ That message is also conveyed by 'parent education' courses. These programmes, 
developed in conjunction with courts and mediation services, have been running in parts of the USA for some years and there is now a rapid proliferation. ${ }^{59}$ They have been set up as a response to the belief that "uninformed parents are unwittingly using their children and the courts to `get back at' recalcitrant spouses" ${ }^{\prime 60}$ and aim to motivate parents to reduce their hostility towards each other and refrain from taking disputes to court. "They ... provide an early intervention for parents who want to act in the best interests of their children but need education to do so". ${ }^{61}$ In the UK the Department of Health has produced a Parenting Initiative ${ }^{62}$ which includes funding for action projects, as a result of which two mediation services (Coventry and Sussex Family Mediation Services) have been grant-aided to design and pilot an educational pack for parents attending mediation. ${ }^{63}$

The assumption that there exists - unproblematically - a body of relevant knowledge is also made in the White Paper's use of the term 'information' in regard to what is to be conveyed at the first port of call for all those intending to divorce. "This will introduce parties to the benefits of marriage guidance and counselling, [and] provide information about the emotional, psychological, financial and legal aspects of separation and divorce and its effects on parents and children". ${ }^{64}$ The only noted concerns expressed in responses to the Lord Chancellor's Department on this issue are "that the provision of information should not overstep the boundary into advice giving", specifically legal advice giving, and, that "the form of information giving must be entirely objective". ${ }^{65}$ The response to neither concern allows of the possibility that the 'facts' to be conveyed about the process and effects of child adjustment to parental separation are less than fully proven by `scientific' research and that the research, though voluminous, would not support so restricted an image of the child as victim, mainly or exclusively, of parental conflict as that which has become so authoritative in the 1990s. In 1983 Freeman had stated: 'When compared with children who have suffered bereavement, it seems that children from homes who have suffered marital disruption encounter hardships considerably more frequently" ${ }^{\prime 66}$ but the possible range of 'hardships' which could lead to the victimisation of the child were at that stage of the 
debate not subsumed in 'conflict reduction'. Research has since shown, for example that a major hardship in the lives of families after divorce is poverty. ${ }^{67}$ Research has also revealed the extent of spousal abuse and the likelihood that a good proportion of divorcing mothers have suffered violence $^{68}$ which their children have witnessed. ${ }^{69}$ In practice children may be victims of contact rather than lack of contact. ${ }^{70}$

Furthermore the results of research focusing on the effects of parental conflict and separation may not be as conclusive and clear cut as statements in recent policy documents suggest. ${ }^{71}$ Policy in relation to divorce is being influenced by associations between divorce and, for example, educational attainment, criminal activity and employment which do not adequately address `third factor' hypotheses. As Burghes concludes on reviewing research evidence, 'Because the children of intact marriages fare better on average than those who experience separation and divorce, does not mean that preventing the latter would create better outcomes associated with the former.' ${ }^{72}$ The finding of the Exeter Family Study that `family re-ordering(s) had the strongest association with poor outcomes for children ${ }^{13}$ had great public impact ${ }^{74}$ but must be set alongside research like that of Elliott and Richards who have shown that conditions often pre-exist the divorce. In the latter study children whose parents divorced when they were aged 7-16 obtained worse scores for each of their four outcome measures than those whose parents remained married but this was the case at age sixteen after the parental divorce but also at age seven before the parental divorce' [my italics]. ${ }^{75}$

This is not to imply that the research about the psychological harm children may suffer should not be taken seriously. However, there is a strong case that the proposed reforms are not a comprehensive response to such knowledge and will not, therefore, adequately address the interests of children. ${ }^{76}$ The selective reconstruction, within legal and political discourses, of results of research conducted within the 'psy' and social sciences does not include the complexities found in the discussion of such research in scientific journals and does not 
acknowledge the existence of other 'information' about children of divorcing parents. Yet, because the major source of victimisation in legal and political communications is now taken to be that of inter-parental hostility, the sole response is an attempt to reduce parental hostility and promote joint parenting. It is, perhaps, stating the obvious that there are very clear political benefits to the existence of this particular image of the child. In relation to proposed divorce reform, the focus on the child as victim - and parental hostility as the cause of the child's suffering - allows for a policy of mediation rather than the use of solicitors because mediation is seen as a more effective way of reducing hostility and encouraging cooperation. It justifies a move from at the same time, a fault-based divorce law to a process over time and is thought to be a cheaper process than the current usage of lawyers and courts, thereby addressing the problem of the mounting Legal Aid bill. Without a clear image of the child as victim of parental conflict the divorce reforms proposed would be too difficult to `sell', challenging as they do professional, religious and political interests. ${ }^{77}$

There are other economic and political benefits accruing from the current prevailing image of the child as victim of divorce. Had that image not become so powerful, other images of the child as victim in these circumstances might have been more influential. Without a more widely available image of the child as victim of an abusing 'absent' parent it is the 'implacably hostile' mother who continues to be the bogey 'man' of family law: hostility is deemed to have no justification even in the context of (fear of) violence. Furthermore, a focus on the benefits for children of 'stability' would require a range of social welfare policies to ensure greater stability of family life rather than `a time to reflect'. ${ }^{78}$ These policies have much more onerous financial implications and do not fit in with the principle of minimal state intervention. If images of children rooted in other 'dangers' in the situation of parental separation had become more widely available and authoritative the corresponding response would have included much more than divorce mediation and, crucially, would not have placed such stress on the responsibility of parents. Information-giving programmes and mediation processes may have been designed to help 
children and may result in an improvement in the lives of at least some children but the strategy is to reduce conflict by inducing parental guilt. The Michigan and Kansas programmes of parental education with titles like SMILE (Start Making It Livable for Everyone), ${ }^{79}$ GRASP (General Responsibilities as Separating Parents) and Sensible Approach to Divorce ${ }^{80}$ point up the normative function of such courses, which not only reduce pressure on courts but also feed into and reinforce the current political ideology of the family.

\section{IMPLICATIONS FOR CHILDREN}

The image of the child, in relation to parental separation, as victim of hostile, non-cooperative and uncommunicative parents has thus become a semantic artefact of clear utility in the political as well as the legal discourse by enabling family policy to be based on a placing of responsibility for victimisation of the child at the door of one or both parents. ${ }^{81}$ The problem is of course that these prevailing images of children as victims - so useful to policy makers and professional practice - are unlikely to lead to a reformed divorce process and aftermath which are much 'better' for the children involved. Not only is the nature of the victimisation constructed very narrowly but the image of the child as victim of divorce is kept quite distinct from other images of children, for example the child as victim of paternal abuse or victim of poverty (though the child as potential offender is used to strengthen the idea of the child as victim of divorce) and can only be sustained by particular images of parents. The focus on parental action to remove or reduce 'victimisation' caused by parental conflict is sustained by an image of parents capable of cooperation and communication via 'reflection' and 'mediation'. In so far as this image is authoritative then those other available images, for example of parents incapable of joint parenting and as capable of using contact for abusing ex-partner or child, are not reconstructed for use within political and legal discourses. ${ }^{82}$

The White Paper discourages the juxtaposition of different images by discussing separately the 
issue of domestic violence in a chapter dealing with "Related Areas of Family Law and Procedure". ${ }^{83}$ The Consultation Paper had previously explained that one objective of the reforms "would be to separate the divorce process and matters relating to children, home and maintenance from other matters such as molestation and violence by removing the jurisdiction to grant injunctions for molestation and violence ancillary to divorce proceedings" ${ }^{84}$ because the process to divorce "is a separate matter". ${ }^{85}$ This constituting domestic violence as an issue not properly relevant to the divorce process allows the idea that parental cooperation is possible - a necessary precondition for the existence of `a continuing but separated ${ }^{\prime 86}$ traditional family which is the ideological basis of current policy. This means that policy and practice are underpinned by fragmented, partial and compartmentalised images of children which can only disadvantage real children. The welfare of children has been identified so closely with the reduction of conflict that mediation is equated with welfare. As James says, "The welfare principle is reflected in the implicit assumption that encouraging parental responsibility and decision-making, thereby reducing conflict, is the best way of ensuring that the child's welfare is met". ${ }^{87}$

But there is another, perhaps even more important, corollary. As Thane pointed out in relation to late nineteenth and twentieth century legislation, "A succession of statutes ... have striven to protect children from neglect and ill-treatment by parents and guardians ... However at no time was it thought necessary to give children independent voices in such proceedings". ${ }^{88}$ This has been changing, particularly in relation to issues of compulsory care and medical decisions where children are being heard and, sometimes, those voices are determinative of outcome. ${ }^{89}$ Nevertheless, the child of divorce is being portrayed almost exclusively as victim, a potential detriment as the `survivors' of child sexual abuse and domestic violence have made clear in their rejection of the label of victim. ${ }^{90}$ The label inhibits discussion as to whether, in relation to the divorce process, the child should have anything other than a passive role. Instead the image could be that of 'legal actor' and legislation could recognise the autonomy rights of the child ${ }^{91}$ rather than her 'right' to be protected ${ }^{92}$ but debate, now familiar in many areas of child-related law and 
practice, about 'balancing' liberationist and protectionist rights for children, has not yet taken place in relation to divorce law. The idea that separating parents protect their children and must be left free to do so has been largely unchallenged in recent debates. But, as Roche points out, the family and community can act to the disadvantage of children and the "recognition of the possibility of the child having interests which are independent of family and community leads us to a consideration of how such interests might be expressed and how the wider community should respond to such a voice". ${ }^{93}$ This consideration has been precluded in relation to divorce by the construction of only one 'independent' image of the child - that of the child 'battered' by parental conflict. The child rarely has needs voiced other than those relating to inter-parental conflict and rarely has a status other than that of victim. Roche therefore makes the timely point that "the issue now is one, not of establishing the principle of children's rights, but of extending the range of situations where the language is perceived as legitimate" (1995, p. 292). ${ }^{94}$

This criticism that the child is being given no independent voice in the divorce process and that divorce reform proposals do not give sufficient priority to the welfare of the child has led to a response from within the mediation movement, a response already apparent in the USA where strategies for 'empowering' children "to reduce children's victimisation and enable them to emerge as winners" are already being discussed and implemented. ${ }^{95}$ With such a crucial role for mediation in the reform proposals mediators have little option but to develop ways in which the welfare of the child, and indeed her rights, can be addressed in the process of mediation without undermining the fundamental premise of mediation that it allows parent control and determination of outcome. ${ }^{96}$ So National Family Mediation (NFM) in 1993-4 conducted a study of the views and practices amongst mediators in regard to the role of children in mediation. Their Report concluded:

In relation to arrangements for children, the perspective of those children is a crucial part of the information necessary for decision-making. This information can be introduced into the mediation in two ways: i. by parents themselves or ii. by direct consultation with children within the process. Whether children should be consulted directly, how or at what stage in the process are matters to be agreed jointly by the mediators and parties. ${ }^{97}$ 
Therefore NFM has devised new training schemes for mediators to help parents consult their children or mediators to 'consult' children directly. ${ }^{98}$ Yet, as Richards points out, this innovation "cannot square a circle" as "there is no way in which they could use information that a child may give them without destroying their own neutral position". ${ }^{99}$

The attempt to provide the child with an active role in a scheme developed with an image of the child as victim may be doomed to failure and it may be that the child as legal actor should not necessarily supplant the child as victim in this context. ${ }^{100}$ Furthermore, as Fox Harding points out, "a stress on children as independent actors may in fact be a smoke screen used to legitimate the withdrawal of the state from responsibility for the upbringing and maintenance of them". ${ }^{101}$ Instead of such a polarised discussion two possibilities need further consideration. First that there may be understandings of children and their needs other than that of the child as victim of parental conflict and that these images may have quite different implications. Secondly, that the image of an abstract child may be so powerful that it inhibits or prevents discussion of the needs of the actual child, that is the child who becomes the focus of procedures. ${ }^{102}$ At the very least, therefore, Roche's comment that "Children are talked about. What needs to change is how they are talked about and how children can connect with and participate in such conversations"103 should be relevant in relation to discussions of divorce reform.

\section{THEORETICAL FRAMEWORKS}

These discussions require a clearer theoretical perspective on what brings people to see children and families in particular ways: how and why our images of children are developed, and how, as a result, concern is expressed, by those operating within one or more social systems, about particular `harms' to children. As King has argued,

Taking, as we have done, the starting point of harm to children, it is then possible, using a closed system approach, to examine how each of these systems, which are treated by society as authoritative, understands and gives meaning to communications from other systems concerning 'harm to children'. ${ }^{104}$ 
King is arguing on the basis of autopoietic theory but a similar message is given by Rex and Wendy Stainton Rogers in their book subtitled "Shifting Agendas of Child Concern" which takes a polytextualist approach to the analysis of discourse relating to 'child concern'.

A critical polytextualist analysis of these discourses seeks to address them as socially constructed ... stories, and to pursue child concern within the recognition that it belongs to and cannot be separated from the social-tectonics of social thinking in general terms. It offers not an understanding of children concern per se so much as a concern about concern. ... we believe it is crucial to be able to highlight and discuss the child oppressive potentials of each, without being immediately accused either of merely attacking the well-meaningness of those who argue for them, or of failing to acknowledge the danger of our challenge. ${ }^{105}$

As the authors point out in their concluding chapter, the alternative, "To embark on a crusading quest for villains", is an exercise which puts its operator "within a chimerical fairy-tale world in which, once the brave knight has slain the dragon, children can all live `happily ever after"'. ${ }^{106}$ Applying knowledge about the effects of parental conflict on children in the abstract may slay the dragon of parental conflict and may improve the lives of some actual children but it will leave untouched and unnoticed other sources of harm. To quote King again, referring to past difficulties in 'solving' the problems of child protection, The difficulty ... was that each system's vision of what constituted society, was restricted by its own selectivity ... Both together and separately their communicative codes produced within each system versions of modern society which reduced anything which did not have meaning for them to the status (or rather non-status) of 'noise' [which] consisted of whatever could not be explained using the programmes available to the system, but, nevertheless, had to be acknowledged as existing. ${ }^{107}$

A phenomenon 'known' in one closed system is 'unknowable' (noise) in another system ${ }^{108}$ with the result that policies are based on a simplified vision. They may also be based on a distorted vision. Currently, the image of the child of divorcing parents which is conveyed through legal and political communications relies on knowledge reconstructed from systems external to law and politics. This gives the impression that there is a consensus across systems of law, politics, 
economics and the social and medical sciences but this masks differences in meaning and authority. In terms of autopoietic theory, what is occurring is 'interference'. Teubner defines this as the phenomena that occurs when "communications that apparently bridge both [or several] discourses are in reality separate pieces of information ... coupled only by their synchronization and coevolution"109 so that what results is 'confusion' arising from different ways of thinking about children in different discursive systems. What is missing is acknowledgement of how and why separate systems construct and reconstruct truths embodying particular understandings of what is 'good' and 'bad' for children. If this type of analysis is taken on board then it becomes at least possible to make visible a much wider range of images of children and to locate those systems, as well as their inter-relatedness and their limits, where such images can be responded to in ways that are most likely to meet the complex and varied needs of children. ${ }^{110}$

\section{REFERENCES}

1. Lord Chancellor's Department, Looking to the Future: Mediation and the Ground for Divorce (1995, Cm 2799) London: HMSO.

2. James. A. and Lyons, C., Editorial, J. Social Welfare and Family Law (1995) Vol. 17 No. 3, pp. iii-vi at pp. iv and $\mathrm{v}$ respectively. For detailed criticisms of the proposals see Richards, M., 'But What About the Children? Some reflections on the divorce White Paper', Child and Family Law Quarterly (1995) Vol 7, No 4, 223 and Douglas, G., Murch, M. and Perry, A., 'Supporting Children When Parents Separate - A Neglected Family Justice or Mental Health Issue' Child and Family Law Quarterly (1996) No. 2. In addition, nineteen child care agencies and professional bodies issued a joint statement drawing attention to the lack of attention to the needs of children in the Family Law Bill 1995: see Newman, G. in Childright (1996) No. 124, p. 2.

3. Lord Chancellor's Department, Looking to the Future: Mediation and the Ground for Divorce, (1993, Cm 2424) London: HMSO.

4. Tufte, V. and Myerhoff, B. (eds), Changing Images of the Family (1979) Yale University Press at p. 9.

5. $\quad$ Op cit n 3 on pp. iii and iv of the Foreword by the Right Honourable the Lord Mackay of Clashfern.

6. $\quad$ Op cit n 1 at para. 5.1.

7. $\quad$ Ibid para. 2.12. 
8. $\quad$ Ibid para. 2.13 .

Ibid para. 2.21.

10. Ibid paras 2.22-2.23. The remaining four criticisms are: "The system is unjust", "The system is confusing and misleading and often open to abuse", "The system is discriminatory" and "The system distorts parties' bargaining positions".

11. Cockett, C. and Tripp, J., Family Breakdown and its Impact on Children (1994) Exeter University.

12. $\quad$ Op cit n 1, para. 5.16. Para. 5.15 also refers to the Joseph Rowntree funded research into comprehensive mediation in relation to the effectiveness of mediation in "reducing bitterness and tension".

13. Para. 3.11 mentions that this is the consequences "for themselves and their children".

14. $\quad$ Op cit n 3 at para 5.11.

15. Law Commission, The Ground for Divorce (1990, Law Com No. 192) London: HMSO at para. 2.19.

16. $\quad$ Op cit n 1 para. 3.5 .

17. Ibid para. 3.5 .

18. Ibid para. 4.37.

19. Ibid para. 5.16.

20. $\quad$ See also paragraphs 4.6 and 4.13.

21. $\quad$ Op cit n 1 para. 5.11 .

22. Ibid para. 5.24 .

23. Ibid at paras 5.17 and 5.21.

24. Ibid para 7.4. Currently the provisions for attendance at information sessions, when the benefits of mediation and the needs of children would be conveyed, are to be found in Clause 8 of the Family Law Bill 1995. It would be "a meeting organised in accordance with regulations made by the Lord Chancellor" (cl 8(4)) and so no details are as yet available.

25. This image has been strengthened by an amendment to the Family Law Bill 1995 conceded by the Lord Chancellor so that the hardship bar to divorce existing in current and proposed divorce law will be modified to refer to 'substantial' (instead of 'grave') financial or other hardship and to children as well as the spouse. Though this has significance within the context of this discussion it may not have much practical significance given the marginal applicability and use of the current provision.

26. Thane, P., 'Childhood in History' in King, M. (ed.) Childhood, Welfare and Justice (1981) Batsford at p. 15. For a discussion of the development of wardship and the inherent jurisdiction see Bromley, P. and Lowe, N., Bromley's 
Family Law (1992, 8th Edition) Chapter 14.

27. Thane op cit n 27 at p. 18.

28. The Factory Acts of the nineteenth century provide voluminous evidence of legislative concern for children as victims of employers. For a detailed analysis of the history of such concern see Pinchbeck, I. and Hewitt, M. (1973) Children in English Society Volume II. For a survey of those offences created to protect children and young persons by criminalising particular acts when committed against minors, see Bainham, A., Children, the Modern Law (1993) Bristol: Family Law at pp. 474-486 and Bevan, H.K., Child Law (1989) London: Butterworths, chapter 9. It is, however, problematic whether much of this legislation properly feeds into an analysis of the 'child' as victim in that much is concerned with the regulation of the sexuality of women and girls. For example, in R v Tyrrell C.C.R. [1894] 1 QB 710, which held that a young girl is deemed to be incapable of consent (and so not guilty of aiding and abetting) in relation to section 5 of the Criminal Law Amendments Act 1885, Lord Coleridge, C.J. stated: "The Criminal Law Amendment Act 1885, was passed for the purpose of protecting women and girls against themselves" (at p. 712). Male children were not so protected.

29. See King, M. and Piper, C., How the Law Thinks About Children (1995, 2nd ed.) Aldershot: Arena, chapter 4: 'The Child As Semantic Artifact', especially pp. 64-7.

30. Teubner, G., 'How the Law Thinks: Towards a Constructivist Epistemology of Law' Law and Society Review (1989) Vol. 23, No. 5, 727-57 at p. 741.

31. The child as victim is therefore one of several constructs such as the child as as witness, as a bundle of needs or as a bearer of rights. See King, M. and Piper, C. op cit n 29 at p.64.

32. As Zedner comments, "Studying victims has become one of the growth industries of criminology" (Zedner, L., "Victims" in Maguire, M. et al (eds) The Oxford Handbook of Criminology (1994) Oxford: Clarendon at p. 1207.

33. $\quad$ Morgan, J. and Zedner, L., Child Victims (1992) Oxford: Clarendon Press at p. 5.

34. $\quad$ See La Fontaine, J., "How Do the Bullied See Bullying?" Childright (1992) No. 83, 7-8.

35. See Mullender, A. and Morley, R. (eds), Children Living with Domestic Violence: Putting Men's Abuse of Women on the Child Care Agenda (1994) London: Whiting and Birch; O'Hara, M., "Domestic Violence and Child Abuse - Making the Links" Childright (1992) No. 88, 4-5.

36. $\quad$ Morgan and Zedner, op cit n 33.

37. Zedner, op cit n 32 at p. 1230.

38. Morgan and Zedner, op cit n 33 at p. 20.

39. $\quad$ Flowers, R., Children and Criminality: The Child as Victim and Perpetrator (1986) Connecticut: Greenwood Press a p. 187.

40. Peelo, M. and Stewart, J., 'Trashing and Looting' Probation Journal (1992) Vol. 39, No. 3, 138-42. See also Walklate S., Victimology: The Victim and the Criminal Justice Process (1989) Unwin Hyman. 
41. $\quad$ Freeman, M., The Rights and Wrongs of Children (1983) London: Pinter.

42. Freeman op cit n 41 at pp. 191 and 192 referring to Wallerstein, J. and Kelly, J. Surviving the Breakup (1980) New York: Basic Books.

43. Cmd 9678 (the `Morton Commission'). See `Family Law, Review of Child Law: Custody', Law Commission Working Paper No. 96 (1986) HMSO, for a summary of the arguments of the Morton Commission which led to their decision to recommend that court approval of arrangements be a condition precedent for divorce and also for reference to the Denning Committee (Final Report of the Committee on Procedure in Matrimonial Causes 1947, Cmd 7024) and a nonenforceable provision in the Matrimonial Causes Rules 1947.

44. Inter-Departmental Committee on Conciliation (1983) Robinson Report.

para. 5-1; see also para. 5.5.

45. Op cit n 3.

46. $\quad$ Op cit $n 1$ at para. 3.10 .

47. Pearce, N. 'First Impressions of the Children Act: A Judge's Assessment' Family Conciliation (1992) Vol. 2, No. 1, 1013 at p. 10.

48. $\quad$ Roche, J. 'The Children Act 1989: Once a Parent Always a Parent?' J. of Social Welfare and Family Law (1991) No 5, 345-61 at p. 355.

49. $\quad$ Ibid p. 346.

50. $\quad$ Children Act 1989 s2.

51. For a discussion, see Piper, C. 'Marketing the Children Act 1989: the invisibility of mothers and fathers,' Paper presented at the Annual Conference of the Social Policy Association, July 18 1995, Sheffield Hallam University.

52. See case notes on Re O (Contact: Imposition of Conditions) [1995] 2 FLR 124 by Jolly, S., 'Implacable Hostility, Contact and the Limits of Law' Child and Family Law Q. (1995) 228-35 and Piper, C., 'Court of Appeal: In re O (A Minor) (Contact: Imposition of Conditions)" (Case Note) J. Social Welfare and Family Law (1995) Vol. 17, No. 3, 3559.

53. See a recent article by Weyland, I., 'Judicial Attitudes to Contact and Shared Residence since the Children Act 1989' J. of Social Welfare and Family Law [1995] Vol. 17(4) 445-59) which compares and contrasts case law on contact and shared residence before and after the Children Act 1989.

54. In legal communications, the image of the child as victim of divorced or divorcing parents is further defined by a particular construction of the victimising parent. Such a parent is not the 'absent' parent who does not seek or maintain contact but rather the custodial parent who is 'implacably hostile' to contact and refuses to cooperate in arrangements for contact. This cannot solely be explained by the lack of procedures to enforce contact on non-custodial parents but rather by an over-riding aim to remove, not create, parental conflict. (See Piper op cit n 52).

55. $\quad$ Mv M (child: access) [1973] 2 All ER 81 per Wrangham J. 
Jones, E. and Parkinson, P., (1995) 'Child Sexual Abuse, Access and the Wishes of Children' Int. J. of Law and the Family (1995) Vol. 9, No. 1, 54-85 at p. 55. They use the phrase "in the past" because they later discuss an Australian case which suggests different assumptions being held by judges. They argue that currently the underlying assumption in the reported cases "is that if a sexually abused child could have contact with the perpetrator in a relationship which was free from further abuse, then contact would be desirable" and that they "seek to question that assumption" (p. 56).

58. Indeed the White Paper states: "It is doubtful whether further research on the effectiveness of mediation can do more than reiterate the available evidence which is considerable, and supportive of the benefits attributed to mediation" (op cit $\mathrm{n} 1$ para 5.20). In this context it is interesting to remember that the 19th century ideology of women as subordinate to men, physically and mentally, which underpinned much regulation, was supported by science and medicine as well as religion. See Ehrenreich, B. and English, D., For her Own Good: 150 Years of the Experts' Advice to Women (1979) London: Pluto Press.

59. $\quad$ See Lehner, L., (1994) "Education for Parents Divorcing in California" Family and Conciliation Courts Review (1994) Vol. 32, No. 1, 50-4 and Petersen, V. and Steinman, S., (1994) "A Court-Mandated Educational Program for Divorcing Parents" Family and Conciliation Courts Review (1994) Vol. 32, No. 1, 27-39. See also the Special Issue of the Family and Conciliation Courts Review entitled "Parent Education in Divorce and Separation" (1996) Vol. 34, No. 1, which includes 8 articles on the subject. The first article (Salem, P., Schepard, A. and Schlissel, S. "Parent Education as a Distinct Field of Practice" pp. 9-22) points out that there are now more than 560 programmes throughout North America (at p. 10).

60. Geasler M. and Blaisure, K. 'Court Connected Programs for Divorcing Parents in Michigan', Family and Conciliation Courts Review (1995) Vol. 33, No. 4, 484-94 at p. 484.

61. Salem, P. 'The Emergence of Parent Education Programs in the United States' Family Mediation (1995) Volume 5, No 1, 5-7 at p. 5.

62. Announced by Virginia Bottomley, then the relevant Minister, 8 December 1994.

63. Family Mediation (1995) 'Education for Separated Parenting' Volume 5, No. 1, at p.4. In North America, as Salem et a note: "a market has developed for parent education products and services ... Some programs offer complete packages that include training, videotapes, instructor manuals, and participant workbooks" (op cit n 59 at p. 10).

64. $\quad$ Op cit n 1 para. 2.37.

Op cit $\mathrm{n} 1$ at paras 7.8 and 7.12 respectively. The White Paper therefore draws a distinction between legal information and advice (at para. 7.9), a distinction which Cretney argues is untenable ('Divorce Reform in England: Humbug and Hypocrisy or Smooth Transition?' in Freeman. m. (ed), Divorce Where Next? (1996) Dartmouth at pp. 47-8).

66. Freeman op cit n 41 at p. 191.

Fineman, M., The Illusion of Equality (1991) Chicago and London: University of Chicago Press; Weitzman, L., The Divorce Revolution: The Unexpected Social Consequences for Women and Children in America (1985) New York: Free Press. 
68. For a review of the literature see Kaganas, F. and Piper, C., 'Domestic Violence and Divorce Mediation' J. of Social Welfare and Family Law (1994) No. 3, 265.

69. $\quad$ Mullender and Morley, op cit n 35.

70. Hester, M. and Radford, L., 'Domestic Violence and Access Arrangements for Children in Denmark and Britain' J. of Social Welfare and Family Law (1992) No. 1, 57-70; Jones and Parkinson, op cit n 57.

71. $\quad$ Piper, C., (1994) "Looking to the Future' for Children" Journal of Child Law (1994) Vol. 6, No. 3, 98; Utting, D., Bright, J. and Henricson, C., Crime and the Family (1993) Occasional Paper 16, London: Family Policy Studies Centre. See also Children and Violence, Report of the Commission on Children and Violence convened by the Gulbenkian Foundation (1995) at pp. 46-8.

72. $\quad$ Burghes, L., Lone Parenthood and Family Disruption: The Outcomes for Children (1994) Occasional Paper 18, London: Family Policy Studies Centre, p. 49. See also Utting et al op cit n 71: 'The extent to which marital breakdown and delinquency are related is, in fact, a rich source of confusion' (p. 19).

73. $\quad$ Cockett, M. and Tripp, J., Children Living in Re-ordered Families (1994) Joseph Rowntree Foundation Social Policy Research Findings No. 45 (February) p.3.

74. James and Lyon, for example, have drawn attention to this, in referring to "the furore surrounding the pre-publication release and related television coverage last year of findings from the Exeter family study" (op cit n 2 at p. iv).

75. Elliot, J. and Richards, M.P.M., "Children in Divorce: Educational Performance and Behaviour Before and After Parental Separation" International Journal of Law and the Family (1991) Vol. 5, 258 at p. 274.

76. $\quad$ See Richards op cit $\mathrm{n} 2$ and Douglas et al op cit $\mathrm{n} 2$.

77. Indeed at the time of writing there is no confidence that these proposals will become law, given the history of the Domestic Violence and Matrimonial Homes Bill 1995 and the tenor of the debate in both House of Parliament over the Family Law Bill 1995. In relation to that debate the strongest challenge to the Bill has been via the construction of an alternative image of the child as harmed by divorce itself.

78. The phrase used to describe the period of one year between filing this intention to divorce and divorce being granted under the new proposals.

79. $\quad$ See Geasler and Blaisure, op cit n 60 at p.486.

80. Salem op cit n 61 .

81. In the same way legal communications focus blame only on individuals (King, M. and Piper, C. op cit n 29 at p. 66) though, paradoxically, this image of the child as victim is not promoting the 'legalisation' of disputes but, rather, is being used to justify a move from the legalisation of disputes towards informal ordering and non-intervention by the state.

82. Some images cannot be reconstructed within other discourses because they do not 'make sense' to that discourse. See n 108 below. 
83. $\quad$ Op cit $n 1$, chapter 9.

84. $\quad$ Op cit n 3 at para. 10.2 .

85. Ibid para 10.3. Interestingly the sudden demise of the Domestic Violence \& Matrimonial Homes Act led to inclusion of provisions regarding domestic violence in the Family Law Bill 1995, albeit in a separate Part III.

86. For a discussion of the images of the separated family which are constructed in mediation see Piper, C., The Responsible Parent (1993) Harvester Wheatsheaf: Hemel Hempstead.

87. James, A., 'Social Work in Divorce: Welfare, Mediation and Justice' Int. J. of Law and the Family (1995) Vol. 19, 25674 at pp. 217-3.

88. $\quad$ Op cit n 26 at p.19.

89. Fox Harding, L., '"Children's Rights" in Recent Government Policy`Paper presented at a conference on Government Policies and their Effects on Children, University of Central Lancashire, 6 September 1995. Fox Harding discusses, inter alia, the Children Act 1989 and legislation relating to the child as witness. See also Franklin, B. (ed.), The Handbook of Children's Rights: Comparative Policy and Practice (1995) Routledge: London; Freeman, M., 'Taking Children's Rights More Seriously' in Alston, P., Parker, S. and Seymour, J. (eds) Children, Rights and the Law (1992) Oxford: Clarendon Press.

90. See, for example, MacLeod, M. and Saraga, E., 'Challenging the Orthodoxy: Towards a Feminist Theory and Practice Feminist Review (1988) No. 28, 16-51.

91. Roche, J., 'Children's Rights: in the name of the child' J. of Social Welfare and Family Law (1995) Vol. 17 No. 3, 281300 at p. 281.

92. However, as Freeman pointed out, "With divorce it is easier to identify the wrong that children suffer than to spell out any code of rights" (op cit n 41 at p.192).

93. Roche op cit n 91 at p.292. Douglas et al make the same point: "The key question is what, if anything, can be done by way of community support to help children through the critical transitions that follow the break-up of their parents' relationship?" op cit n 2.

94. Roche op cit n 91 at p. 292. As an example he gives the fact that while the Local Authority Social Services Departments have to take notice of the language of rights, Education Authorities do not.

95. $\quad$ See Schwartz, L., "Enabling Children of Divorce to Win" Family and Conciliation Courts Review (1994) Vol. 32, No. 1,71 .

96. $\quad$ The White Paper (op cit n 1) discusses "Children's interests" in relation to mediation at paras 5.31 - 5.33, noting that mediator "are required by their code of practice to remind parents of their duty to take account both of the welfare of their children and their children's views, where these are ascertainable (pp. 45-6). An amendment to the Family Law Bill 1995 goes further by imposing a statutory duty to do so by stating that the mediator must ensure "that the parties are encouraged to consider the welfare, wishes and feelings of the children' (Clause 24(6)). 
97. $\quad$ Giving Children a Voice in Mediation: report produced by National Family Mediation (1994) at p. 20.

98. Fisher, T., 'The Rights of the Child in Mediation and Divorce' Child Care Forum (1996) Issue 9 at p. 14. See also Best, R., "Direct Consultation with Children: A Progress report on Training Modules" Family Mediation (1995) Vol. 5, No. 3, 8 for details of the training proposed.

99. $\quad$ Op cit n 2 at pp. 224 and 225.

100. The image of the child 'as actor' in relation to offending has not proved to be to the benefit of children who offend because the imputation of culpability rather than vulnerability leads to their being placed in penal establishments.

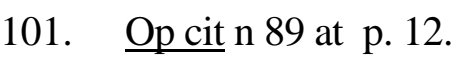

102. Similarly Cunningham has noted, "Both 'children' and 'childhood' appear in my title because we need to distinguish between children as human beings and childhood as a shifting net of ideas" (Cunningham, H., Children and Childhood in Western Society Since 1500 (1995) London: Longman at p. 1).

103. Roche op cit n 91 at p. 293.

104. King, M. A Better World for Children, Explorations in Morality and Authority (forthcoming), Routledge, chapter 7.

105. Stainton Rogers, R. and Stainton Rogers, W., Stories of Childhood, Shifting Agendas of Child Concern (1992) Hemel Hempstead: Harvester Wheatsheaf at p. 83.

106. Ibid p. 190.

107. $\quad$ Op cit n 104 , chapter 4.

108. An example of 'noise' is the phenomena located by Jones and Parkinson, op cit n 57, who, after reviewing both English case law regarding contact in cases of sexual abuse and also psychological interpretations of the effects on the child of sexual abuse, note that law does not take into account the latter knowledge because it can operate only in terms of sexual abuse as an event or series of events (at p. 77): it cannot 'know' the complexities knowable within the psy-sciences.

109. Teubner, G., personal communication, quoted in King and Piper op cit n 29 at p.33. Therefore "Information is always created internally but in the case of interference created simultaneously and from the same communicative event participating in more than one social sub system" (Teubner, G., 'Social Order from Legislative Noise: Autopoietic Closure as a Problem for Legal Regulation' in Teubner, G. and Febbrajo, A. (eds) State, Law and Economy as Autopoietic Systems (1992) European Yearbook of the Sociology of Law, Giuffe: Milan at p. 631).

For example, Joan Kelly recently addressed a joint meeting of members of the Family Law Bar Association and the Solicitors' Family Law Association (Middle Temple Hall, London, November 2, 1994). She summarised her research on siblings from high conflict families, noting that some children were so traumatised by their experiences of violence that they could not recover unless cared for separately from their siblings. By the end of that meeting members of the legal profession were reconstructing that knowledge as a legal guideline that siblings could be separated via care proceedings in their own best interests. There was no shared 'truth', simply parallel legal and psychotherapeutic communications. (Personal notes.) 
110. Douglas et al op cit n 2 have, for example, suggested that discussion be conducted in a mental health framework by applying a crisis model of intervention to helping children adapt to family breakdown. They specifically note that in suggesting the application of this model "we do not infer that we regard children in these circumstances as victims". 